Original Article

\title{
28-HOMOCASTASTERONE: A NOVEL DIETARY PHYTO KETO OXYSTEROL MODULATING TESTICULAR STEROID METABOLISM AND LXR mRNA EXPRESSION IN DIABETIC RAT
}

\author{
VELAN ATHITHAN ${ }^{1}$, RAMASAMY RAMESH ${ }^{2}$, KOTTEAZETH SRIKUMAR $^{*}$
}

${ }^{1}$ Department of Biochemistry and Molecular Biology, School of Life Sciences, Pondicherry University, Pondicherry 605014, India, ${ }^{2}$ Department of Biochemistry, Jawaharlal Institute of Postgraduate Medical Education and Research-Karaikal, Karaikal 609602, India Email: ketoathi@gmail.com

Received: 20 Nov 2017 Revised and Accepted: 04 Jan 2018

\section{ABSTRACT}

Objective: Present study aims to investigate 28-homocastasterone (28-HC) influences on testicular tissue in the normal and diabetic rat.

Methods: Induction of diabetes was achieved by single peritoneal injection of streptozotocin $(60 \mathrm{mg} / \mathrm{kg} \mathrm{b}$. wt) followed by $28-\mathrm{HC}(100 \mu \mathrm{g} / 150 \mathrm{gm}$ body weight) administration by oral gavage for 15 consecutive days to experimental rats. 3 $\beta$-hydroxysteroid dehydrogenase, $17 \beta$-hydroxysteroid dehydrogenase activities, testosterone level, Liver X Receptor (LxR) mRNA expression, malondialdehyde (MDA), reduced glutathione (GSH) and testis histology was analysed.

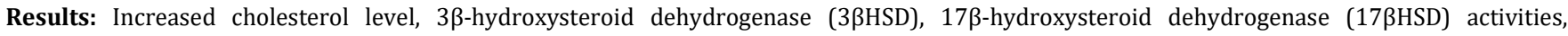
testosterone level with significant elevation of LxR- $\alpha$ and $\beta$ mRNA expression in treated rat testis. A significant reduction found in MDA and increased reduced GSH along with improved testicular architecture was observed.

Conclusion: In the present study demonstrated that 28-HC induced 3ßHSD, $17 \beta$ HSD enzyme activity and testosterone level, thus indicative of steroidogenic potential and capable of transactivating LxR- $\alpha$ and $\beta$ molecular operative in rat testicular tissue.

Keywords: 28-Homocastasterone, Oxysterol, Diabetic, Steroidogenesis, Liver x Receptor

(c) 2018 The Authors. Published by Innovare Academic Sciences Pvt Ltd. This is an open-access article under the CC BY license (http://creativecommons.org/licenses/by/4.0/) DOI: http://dx.doi.org/10.22159/ijpps.2018v10i2.23779

\section{INTRODUCTION}

Mammalian testicular biology is complex next to the nerves system. There are two biosynthetic events significantly contribute to male reproductive processes are steroidogenesis and spermatogenesis, thus under control of endocrine and exocrine factors peptides or steroids. Testicular steroid metabolism are complex biochemical pathway can be influenced by biologically active dietary signalling factors present at low abundance such as phytosteroids, phytohormones, polyphenols and terpenoids are being considered for their role in human health and disease recently [1]. Studies with phytosteroid showed testicular Liver X Receptor (LxR) transactivations resulted to modulation of several testicular functions, such as steroidogenesis, cholesterol homeostasis and proliferative apoptosis balance affected through regulation of gene expression [2]. Two LxR isoforms have been reported, LxR- $\beta$ was found to be expressed in all the tissues and LxR- $\alpha$ expression restricted in liver, intestine, kidney and spleen. LxRs named orphan nuclear receptor until the oxysterol was recognised as a ligand. Oxysterol are an oxygenated derivative of cholesterol, synthesised in mammalian tissues (endogenous oxysterol) at lower levels example, 24-hydroxycholesterol, 24, 25-hydroxycholesterol and thus regulating cholesterol, glucose homeostasis in animal tissues [3]. Upon the ligand binds of the binding pocked and induces receptor structural conformation changes leads to dimerization with retinoid $\mathrm{X}$ receptor $(\mathrm{RxR})$ than translocated into nuclease were its binds to gene promoter sites for regulation of LxRs targeted gene expressions in the cell [4]. Fatim-Zorah et al. cell culture studies reported that LxR- $\alpha$ isoform regulates sertoli cell cholesterol metabolism, whereas LxR- $\beta$ regulates leyding cell cholesterol metabolism and testosterone biosynthesis, in contrast, LxRs knockout mice based study the independent role of LxRs in testicular tissue was reported that the LXR- $\alpha$ is highly expressed in the leydig cells and LXR- $\beta$ in sertoli cells and both isoforms are found to be expressed in the germ cells [2]. However, which isoform of LxRs and its specific types of ligands (oxysterol) responses for testicular testosterone production was unclear.
Earlier studies with plant oxysterol 28-homobrasslinoloide (28-HB)

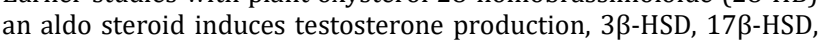
LxR- $\alpha$ and $\beta$ gene expression in normal and diabetic rat testis, proposed that phyto oxysterol modulating rat testicular steroid metabolism through LxRs activation. This study Premalatha et al. failed to specified which isomer of LxRs upregulated by 28-HB, that given the observed effect on diabetic rat testicular tissues [5]. However, 28-HB and 28-HC are active plant hormones comes under the brasslinolide family aldo-keto isomers, both isomers retained anti-glycemic property in diabetic male rat [6]. Nevertheless, elevated plasma triglyceride level was reported in 28-HB (aldo isoform) treated diabetic rat in contrast with 28 -HC (keto isoform) reduced plasma triglyceride level in diabetic rat $[7,8]$. Those observed differential influences on lipid metabolism by orally fed with $28-\mathrm{HB}$ and $28-\mathrm{HC}(100 \mu \mathrm{g} / 150 \mathrm{gm}$ bwt $)$ in diabetic male rat that given attraction towards to study $28-\mathrm{HC}$ role on testicular steroid metabolism.

\section{MATERIALS AND METHODS}

\section{Materials}

All chemicals used were of analytical grade and purchased from Sigma-Aldrich, USA. Testosterone assay ELISA kit purchased from Omega diagnostics, Scotland, UK. Hematoxylin and Eosin were purchased from Himedia, Mumbai, India. 28-HC was courtesy of Dr. V. S. Pori. NCL, Pune, India. Primers were purchased from Eurofins Genomics, Bangalore, India.

\section{Experimental design}

Male albino wistar rats 8-10 w old and weighing about 150-180 gm were purchased from certified laboratory animal supplier Sri Raghavendra Enterprises, Bengaluru, India. They were housed in plastic cages and given atmospheric temperature $\left(25 \pm 5^{\circ} \mathrm{C}\right)$ with a photoperiod of $12 \mathrm{~h}$ light/dark cycle. They were allowed freely access water and standard diet ad libitum throughout of experiment. Animal use and care were strictly followed as per the CPCSEA regulations and Institutional Animal Ethics Committee (IAEC), 
Pondicherry University guidelines (IAEC/Approval. No.2013$14 / 01)$. Rats were divided into four groups of six rats in each, Group I: Normal control, Group II: Control+28-HC $(100 \mu \mathrm{g} / 150 \mathrm{gm}$ bwt), Group III: Diabetic control, Group IV: Diabetic+28-HC $(100 \mu \mathrm{g} / 150$ gm bwt). Induction of diabetes was achieved through a single intraperitoneal injection of $(60 \mathrm{mg} / \mathrm{kg} \mathrm{bwt})$ streptozotocin in citrate buffer (0.1 M, pH 4.5) to $16 \mathrm{hr}$ fasted rats. Blood glucose level was measured, after $48 \mathrm{hr}$ using a glucometer (OneTouch Horizon, Accuva check). Blood glucose level more than $>250 \mathrm{mg} / \mathrm{dL}$ were considered to be diabetic and used for the experiment. Group I and III received 50\% ethanol alone. Groups II and IV received $100 \mu \mathrm{g}$ ( $666 \mathrm{mg} / \mathrm{kg}$ bwt) 28-HC in 50\% ethanol by oral gavage daily for 15 consecutive days.

\section{Preparation of testicular tissue homogenate}

$10 \%(\mathrm{w} / \mathrm{v})$ tissues homogenate was prepared in phosphate buffer (0.1M, pH 7.4) solution. The testicular tissues were homogenized in a motorized Teflon tissue homogenizer (Remi RQ-127A, Remi Motors, Mumbai, India). The homogenates were centrifuged at $10,000 \mathrm{~g}$ in a Sorvall RC 5C refrigerated centrifuge and the supernatant used for the determination of enzyme activity, testosterone, cholesterol, lipid peroxidation and anti-oxidants status employing standard methods.

\section{Estimation of plasma and testicular tissue testosterone}

Plasma and testicular tissues testosterone concentration were determined by using an ELISA kit (Omega diagnostics, Scotland, UK). The assay procedure was strictly followed according to manufacture guidelines. The intensity of the colour developed was measured using ELISA reader and the level of testosterone expressed as $\mathrm{ng} / \mathrm{ml}$.

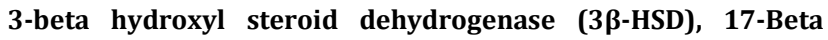
hydroxyl steroid dehydrogenase (17 $\beta$-HSD) activity

The activities of $3 \beta$-HSD was measured by the method of Bergmeyer (1983). 10\% testicular tissue homogenate supernatants were used to determination of the activity of the enzyme. The $2.0 \mathrm{ml}$ of reaction

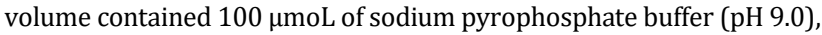
$0.5 \mu \mathrm{mol} \mathrm{NAD}, 0.08 \mu \mathrm{mol}$ dehydroepiandrosterone (substrate), and $100 \mu \mathrm{l}$ of tissue homogenate (enzyme source). Change in absorbance at $340 \mathrm{~nm}$ was a monitor at $20 \mathrm{sec}$. the interval for a $3 \mathrm{~min}$. in the shimadzu UV-VIS double beam spectrophotometer. The activity of the enzymes was expressed as nmol of NAD converted to NADH/mg protein $/ \mathrm{min}$. The activities of $17 \beta-H S D$ were measured by the method of Bergmeyer (1983). 10\% testicular tissue homogenate supernatants were used to determination of the activity of the enzyme. The $2.0 \mathrm{ml}$ of reaction volume contained $100 \mu \mathrm{moL}$ of sodium pyrophosphate buffer (pH 9.0), $0.5 \mu \mathrm{mol} \mathrm{NADPH}, 0.08 \mu \mathrm{mol}$ androstenedione (substrate) and $100 \mu \mathrm{l}$ of tissue homogenate (enzyme source). Change in absorbance at $340 \mathrm{~nm}$ was a monitor at $20 \mathrm{sec}$. the interval for a $3 \mathrm{~min}$. in a spectrophotometer. The activity of the enzymes was expressed as nmol of NADPH converted to NADP/mg protein/min [10].

\section{Determination of lipid peroxidation and reduced glutathione level}

Lipid peroxidation was measured by the method of Ohkawa et al. [1979] and reduced GSH was assayed by the method of Beutler et al. [1963].

\section{Testicular histology}

Following anaesthesia, tissues were immediately surgically removed from the rat and thoroughly washed with $0.1 \mathrm{M}$ phosphate buffer $\mathrm{pH}$
7.4 and transferred to $10 \%$ buffered formalin. After an overnight tissue fixation, further tissues process was carried out in the following serial steps are dehydration with alcohol, clearing with xylene, paraffin infiltration, paraffin embedding the tissues and $4 \mu \mathrm{m}$ size section were cutting with the help of a digitalized microtome (Rotary microtome). The sections ( $4 \mu \mathrm{m}$ size) were stained with haematoxylin and eosin (H/E) stain. The morphological changes of tissues were analysed under camera attached binocular microscopy at $10 \mathrm{x}$ and $40 \mathrm{x}$ magnifications.

\section{Scanning electron microscopy}

Paraffin embedding tissues section ( $4 \mu \mathrm{m}$ size) were used, post section processing steps are deparaffinization with xylene, dehydration with ascending grads of ethanol 20, 40, 60, 80 and $100 \%$ each step given $10 \mathrm{~min}$, followed by $12 \mathrm{~h}$ drying in room temperature. The section was then mounted on stubs, sputtercoated with carbon and visualized under the scanning electron microscope in different magnifications.

\section{Reverse transcriptase polymerase chain reaction}

RNA was isolated from testicular tissues using the TRIzol reagent protocol as for manufacturer guidelines. The cDNA was synthesised from isolated RNA employing reverse transcriptase polymerase chain reaction (RT-PCR) technique by using AMV reverse transcriptase and a total RNA (100 ng) as a template. The cDNA was as a used template to amplify the target gene of interest using genespecific primers are LXR- $\alpha$, Forward primer (5'-3') CCTGATTCTGCAACGGAGTTGTG, Reverse primer (5'-3') CACGTTGTAATGGAAGCCAGAGG and LXR- $\beta$, Forward primer $\left(5^{\prime}-3^{\prime}\right)$ CTCTGCCTACATCGTGGTCATCT, Reverse primer (5'-3') ATGAAGGCATCCATCTGGCAGGT. PCR amplified products were then separated by electrophoresis on a $2 \%(\mathrm{w} / \mathrm{v})$ agarose gel with ethidium bromide stain. The polynucleotide band intensities were measured by densitometry [11].

\section{Statistical analysis}

Experimental results were analysed by one way ANOVA followed by post dock test employed with the statistical software SSSP version 16 (USA). Results were expressed mean \pm SD.

\section{RESULTS}

Measurement of plasma testosterone level in normal and diabetic rat indicated the elevation of this steroid by $20 \%$ following administration of $28-\mathrm{HC}$ to the normal control rat and $67 \%$ increase in the treated diabetic animal using the same amount of 28-HC (table 1). Diabetic control rat, however, registered plasma testosterone level as being $89 \%$ below that of the normal control. Testicular testosterone level was also determined for the control and treated groups of animals. Diabetic rat showed $93 \%$ decrease in testicular testosterone level whereas 28 -HC treated diabetic group yielded 570 $\%$ in this steroid level in the tissue. Treated normal control exhibited 93\% increase in testosterone level in the tissue.

The cholesterol content of testicular tissues showed enhancement of greater than $50 \%$ in the 28 -HC treated normal control animal tissues, whereas $28-\mathrm{HC}$ treatment diabetic animal yielded testicular tissues cholesterol level increased $98 \%$ compared to diabetic control. Diabetic control rat was found to reduce cholesterol level in testicular tissue by $19 \%$ (table 1 ).

Table 1: Testosterone and cholesterol level in 28-HC treated rat

\begin{tabular}{|c|c|c|c|}
\hline Group & Plasma testosterone $\mathrm{ng} / \mathrm{ml}$ & Testis testosterone $\mathrm{ng} / \mathrm{ml}$ & Testis cholesterol mg/gm \\
\hline Control & $4.99 \pm 0.06$ & $1.38 \pm 0.03$ & $5.74 \pm 0.2$ \\
\hline $\mathrm{C}+100 \mu \mathrm{g} 28-\mathrm{HC}$ & $6.0 \pm 1^{\dagger}$ & $2.66 \pm 0.06^{\dagger}$ & $8.74 \pm 0.3^{+}$ \\
\hline Diabetic & $1.8 \pm 0.01$ & $0.10 \pm 0.02$ & $4.65 \pm 0.2$ \\
\hline $\mathrm{D}+100 \mu \mathrm{g} 28-\mathrm{HC}$ & $3.0 \pm 0.08^{*}$ & $0.67 \pm 0.07 *$ & $9.22 \pm 0.1 *$ \\
\hline
\end{tabular}

Values are expressed \pm SD. Group $n=6$. ${ }^{\dagger}$ Group Indicates statistical significance against normal control $(\mathrm{p}<0.05)$. ${ }^{*}$ Indicates statistical significance against diabetic control $(\mathrm{p}<0.05)$.

$3 \beta$ hydroxy steroid dehydrogenase (3ß-HSD) activity noted a $31 \%$ decreased in diabetic control compared to normal control and $93 \%$ increase in the treated diabetic rat. The treated control rat group exhibited $22 \%$ increases in this enzyme activity was also noted. 


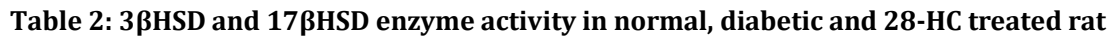

\begin{tabular}{|c|c|c|}
\hline Group & Testis $3 \beta \mathrm{HS} \mathrm{d}$ activity & Testis $17 \beta \mathrm{HS} d$ activity \\
\hline Control & $5.26 \pm 0.48$ & $3.63 \pm 0.45$ \\
\hline $\mathrm{C}+100 \mu \mathrm{g} 28-\mathrm{HC}$ & $6.44 \pm 0.72^{\dagger}$ & $6.94 \pm 0.98^{\dagger}$ \\
\hline Diabetic & $3.63 \pm 0.29$ & $2.92 \pm 0.29$ \\
\hline $\mathrm{D}+100 \mu \mathrm{g} 28-\mathrm{HC}$ & $7.01 \pm 0.95^{*}$ & $9.16 \pm 1.32 *$ \\
\hline
\end{tabular}

Values nmol of NAD converted to $\mathrm{NADH} / \mathrm{mg}$ protein $/$ min. Values are expressed \pm SD. Group $\mathrm{n}=6$. ${ }^{+} \mathrm{Group}$ Indicates statistical significance against normal control $(\mathrm{p}<0.05)$. ${ }^{*}$ Indicates statistical significance against diabetic control $(\mathrm{p}<0.05)$.

$17 \beta$ hydroxyl steroid dehydrogenase (17 $\beta$-HSD) activity observed $20 \%$ reduction of this enzyme activity in diabetic control rat and registering $214 \%$ increased enzyme activity in $28-\mathrm{HC}$ treated a diabetic rat. The treated control showed $91 \%$ increased due to $28-\mathrm{HC}$.

Table 3: Lipid peroxidation and reduced GSH level in 28-HC treated rat testicular tissue

\begin{tabular}{|c|c|c|}
\hline Group & MDA (nmol/min/mg protein) & Reduced GSH mg/mg protein \\
\hline Control & $0.156 \pm 0.02$ & $26.6 \pm 1.92$ \\
\hline $\mathrm{C}+100 \mu \mathrm{g} 28-\mathrm{HC}$ & $0.123 \pm 0.05^{\dagger}$ & $31.52 \pm 1.2^{\dagger}$ \\
\hline Diabetic & $0.417 \pm 0.08$ & $21.37 \pm 1.98$ \\
\hline $\mathrm{D}+100 \mu \mathrm{g} 28-\mathrm{HC}$ & $0.172 \pm 0.04^{*}$ & $54.18 \pm 1.9 *$ \\
\hline
\end{tabular}

Values are expressed \pm SD. Group $n=6$. ${ }^{\dagger}$ Group Indicates statistical significance against normal control $(\mathrm{p}<0.05) .{ }^{*}$ Indicates statistical significance against diabetic control $(\mathrm{p}<0.05)$.

The LxR gene amplicons of rat testicular tissue yielded 90bp band size for LxR- $\alpha$ and $80 \mathrm{bp}$ band size for LxR- $\beta$ and intensity difference of $11 \%$ increase in $28-\mathrm{HC}$ treated control bands of $\alpha$ and $25.50 \%$ increase in 28-HC treated control bands of $\beta$ isoforms was registered. In diabetic treated $12 \%$ and $14.60 \%$ that of LxR- $\alpha$ and LxR- $\beta$ (fig. 3).
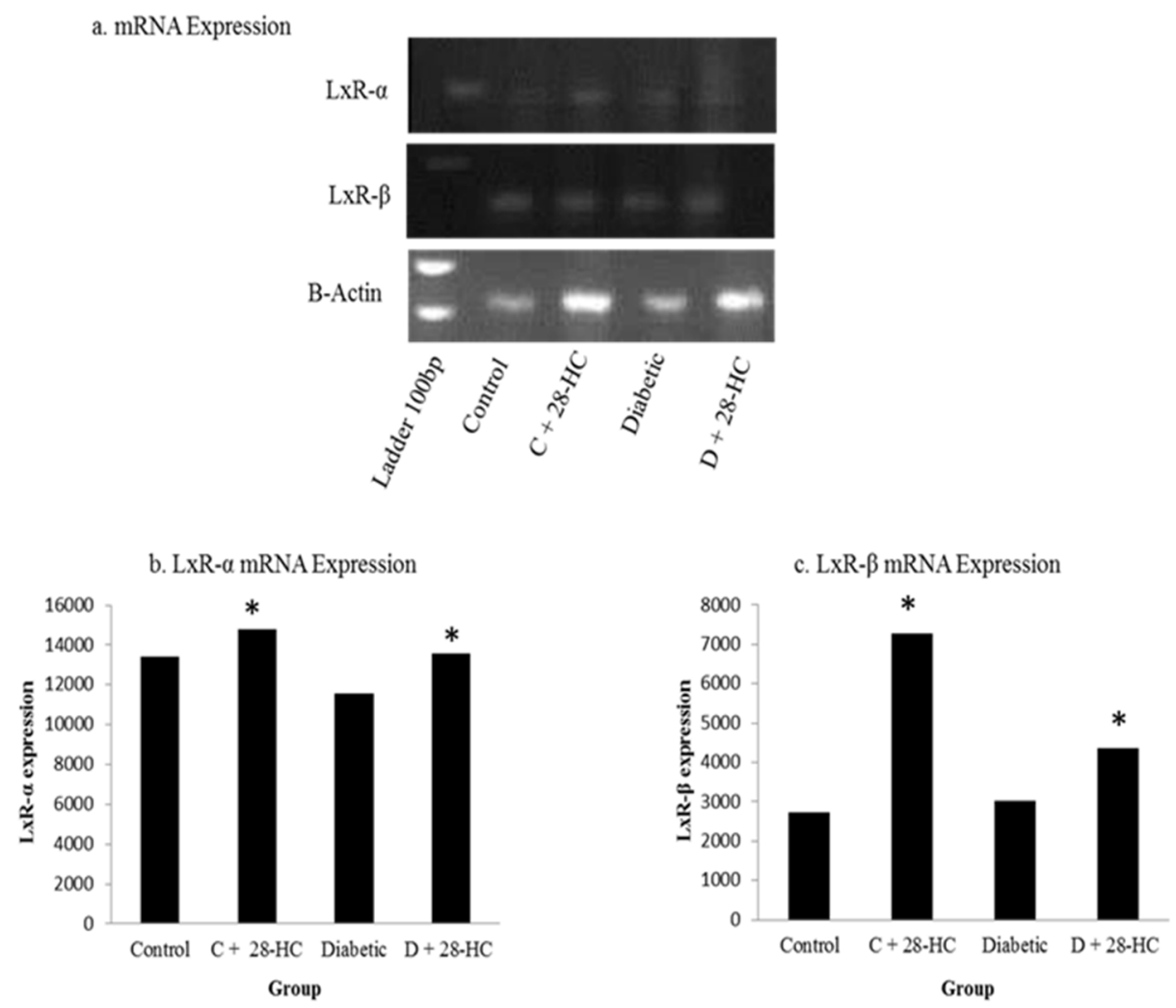

Fig. 3: Testicular LxR- $\alpha$ and $\beta$ mRNA expression following $15 \mathrm{~d}$ oral administration of $28-\mathrm{HC}$. Values are the means \pm SD. Group $\mathrm{n}=6$. ${ }^{*} \mathbf{p}<0.01$ considered to be significant

Spermatogenesis was seen in most of the seminiferous tubules in the normal and normal treated group. Disruption of the architecture of the tubules seen frequently and foci of necrosis seen in few tubules near the periphery and rest of the tubules shows spermatogenesis in the diabetic control group. In a diabetic treated group, most of the seminiferous tubules shows spermatogenesis, few tubules shows disruption of lining membrane and focal areas of necrosis (fig. 1). 

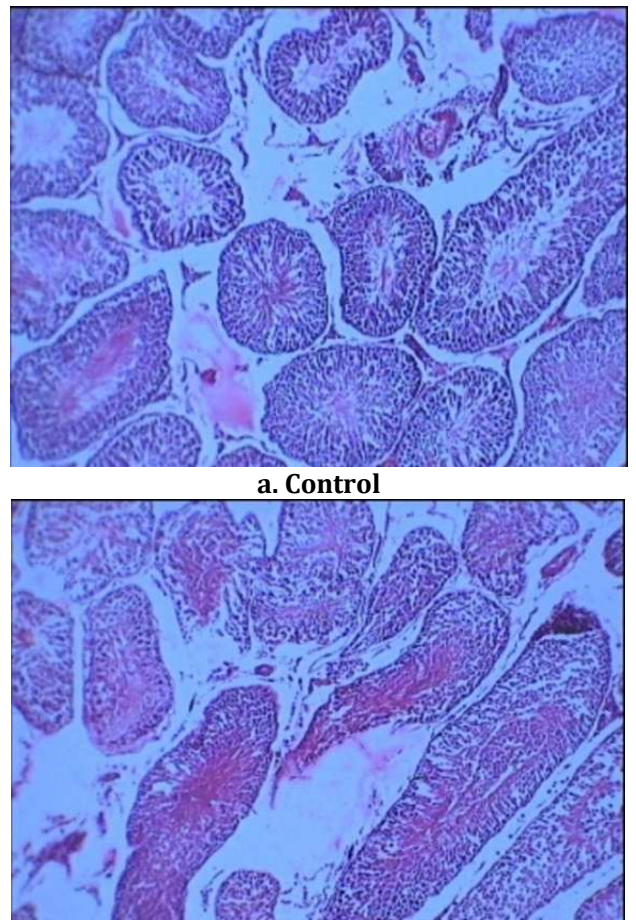

c. Diabetic

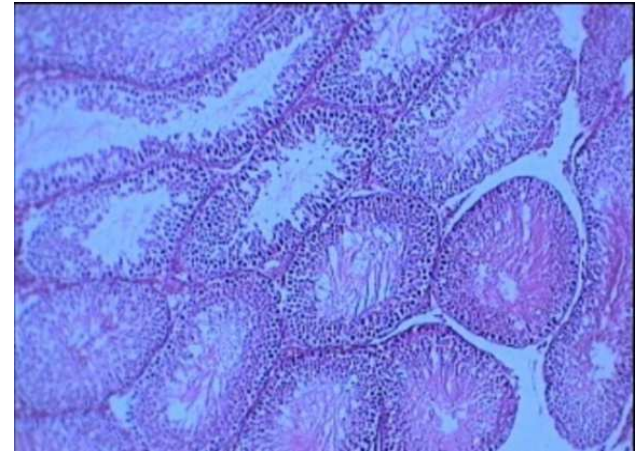

b. Control+28-HC

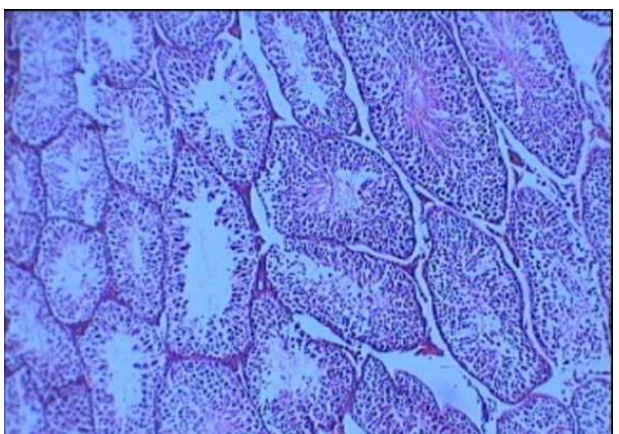

d. Diabetic+28-HC

Fig. 1: Histological sections of testicular tissue (a) Control, (b) Control+28-HC, (c) Diabetic, (d) Diabetic+28-HC following 15 d oral administration of $100 \mu \mathrm{g} 28$-HC Hematoxylin and Eosin Staining at X 400 magnification

Scanning electron microscopic (SEM) examination of the testicular sections $(4 \mu \mathrm{m})$ of the control group showed seminiferous tubules with rounded, regular outlines and all types of germ cells noted close to each other, tubules were completely occupied with the mature spermatids and facing towards the lumen (fig. 2. a). In the control treated group, there is no significant alteration compared to control and observed different stages of spermatogenic cells of spermatogenesis in most of the tubules and abundantly occupied by

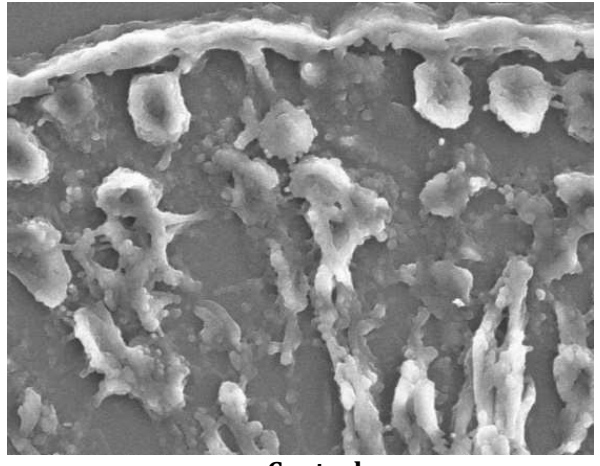

a. Control

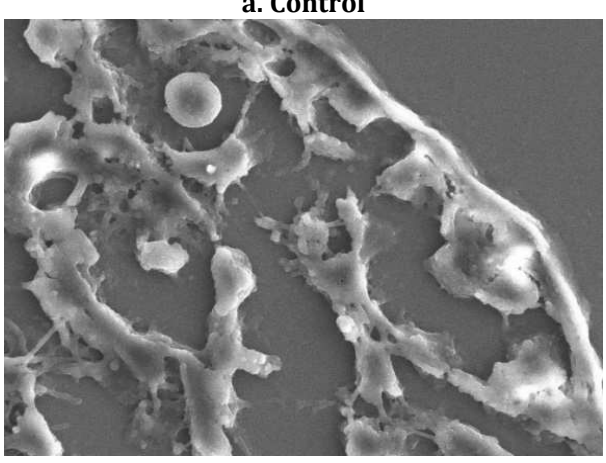

c. Diabetic mature elongated spermatids (fig. 2. b). Diabetic control group was noted that the seminiferous tubules compressed abnormally, irregular intercellular space was observed in between the spermatogenic cells in the tubules (fig. 2. c) and decreased mature spermatids number compared to normal control group. In diabetic treated group shows a significant alteration compared to diabetic control, observed different stages of spermatogenic cells in most of the tubules and abundantly occupied mature elongated spermatids (fig. 2. d).

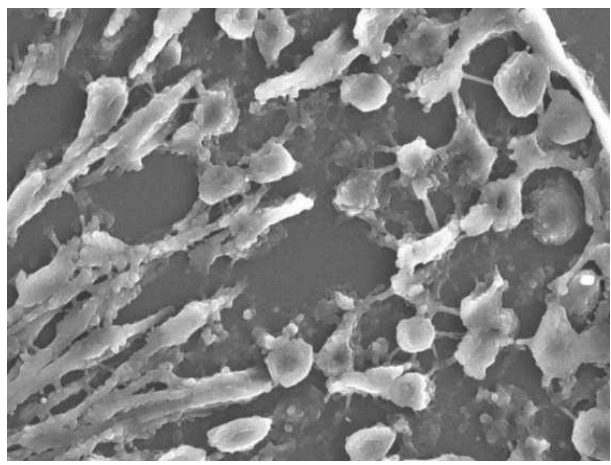

\section{b. $\mathrm{C}+28-\mathrm{HC}$}

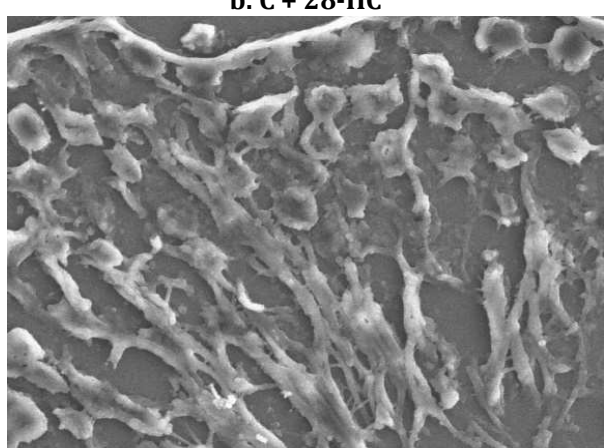

d. D + 28-HC

Fig. 2: SEM for testicular tissue (a) Control, (b) Control+28-HC, (c) Diabetic, (d) Diabetic+28-HC following 15 d oral administration 


\section{DISCUSSION}

Testicular sex steroid concentration is implicated as a marker in evaluating the expression of steroid metabolizing enzymes in a testicular tissue. Since hyperglycemia was known to suppress testis steroid metabolism in the diabetic rat, it provided a basis for evaluating 28-HC influences on rat testicular steroid metabolism. In the present study, orally fed with $28-\mathrm{HC}$ induces changes on testicular $3 \beta$-HSD and $17 \beta$-HSD enzyme activity in STZ induced diabetic rat, parallelly rat plasma testosterone level is also elevated by $28-\mathrm{HC}$ treated normal and diabetic rat suggesting that the elevation in testicular steroidogenic enzyme activity is probably a consequence of the observed elevation in rat plasma testosterone level $[12,13]$. The observed sever decreases in testosterone level and steroidogenic enzyme activity in the diabetic animal considered as a consequent destruction of gonadic function due to hyperglycemia $[14,15]$. 28-HC greatly augmented rat testicular and plasma testosterone level both in treated normal and diabetic rats even though diabetic rat testicular testosterone level was greatly attenuated conforming that this brassinosteroid keto isoform functioned verse similar to the hydroxy form 28-HB in inducing testicular testosterone levels as reported by Premalatha et al. [16].

The plant hormone brassinosteroid isoform 28-HC is now being considered as an additional exogenous oxysterol influencing LxR- $\alpha$ and LxR- $\beta$ function and showing relatively greater expression of LxR- $\beta$ gene expression, than that of LxR- $\alpha$. Earlier reported studies Premalatha et al. using the brassinosteroid isoform 28- $\mathrm{HB}$ had implicated the involvement of LxR- $\alpha$ and LxR- $\beta$ transcriptional regulators in rat testicular steroidogenesis. The observed increase of the biomarkers cholesterol, $3 \beta$-HSD, $17 \beta$-HSD and testosterone is therefore considered as a cellular response of $28-\mathrm{HC}$, through LxRs receptor downstream signalling cascade in the rat testicular cells. The remarkable ability to increase testosterone level by $28-\mathrm{HC}$ in the present study reflects the significant biological potency associated with this compound. However, Premalatha et al. failed to specified which isoform of LxRs gene and protein upregulated by 28-HB, thus given the observed effects on diabetic rat testicular tissues $[5,17$, 18]. On the other hand Fatim-Zorah et al. reported that LxR- $\alpha$ isoform regulates sertoli cell cholesterol metabolism, whereas LxR- $\beta$ regulates leyding cell cholesterol metabolism and testosterone biosynthesis [2]. In the present study a relatively greater LxR- $\beta$ isoform mRNA expression, than that of LxR- $\alpha$ in testicular tissue, suggested that LxR- $\beta$ gene transcription modulating plasma and testicular testosterone levels in rat [19]. Seemingly plant oxysterol 28 -HC retained a differential effect on LxR- $\beta$ gene expression in a mammalian testicular cell. That's suggestive of attempts for drug development for improving diabetic subject testicular steroidogenesis by using oxysterol, LxR- $\beta$ transcriptional regulator a potent target.

Cell biomembrane lipid peroxidation (LPO) is a well-known process of cellular injury and marker for oxidative stress. Cell biomembrane peroxidation generates MDA and measurement of MDA level have been used as a marker of peroxidation status in the cells. Hyperglycemia resulted to increases reactive oxygen species (ROS) generation and induced LPO and protein glycation causes inactivation of the antioxidant enzymes and diminished GSH in the testicular tissues $[20,21]$. Thus effects can be prevented by induction of antioxidants enzymes by oral administration of antioxidant preparation. In the present study, we noted that the increased GSH content and reduction of MDA level following 28-HC treated diabetic rats. Increased oxidative stress and decreased reduced GSH level were also observed in diabetic rat testis. That's the indicative of the 28-HC improved antioxidant status and concomitantly reduced testicular tissue LPO.

\section{CONCLUSION}

Several studies carried out in the past on effect of brassinolide family phytohormones in diabetic rats have shown beneficial effects in terms of antihyperglycemic and antilipidemic. In the present study demonstrated that 28-HC increases 3ßHSD and 17ßHSD enzyme activity, the testosterone level in plasma and testicular cells, thus indicative of the steroidogenic potential and capable of transactivating LxR- $\alpha$ and $\beta$ molecular operative that elucidating the observed responses in rat testicular tissue. Sublimely intake of this phyto oxysterol may improve testicular functions in animal and human.

\section{CONFLICT OF INTERESTS}

Declared none

\section{ACKNOWLEDGEMENT}

The authors acknowledge Dr. V. S. Pori, National Chemical Laboratory (CSIR), Pune, India, for her gift of 28-homocastasterone used in this study. Dr. R. Premalatha, Department of Biochemistry and Molecular Biology, School of Life Sciences, Pondicherry University, for his valuable suggestion and gift of chemicals needs to complete in the present study gratefully acknowledged here. Author V. Athithan, gratefully acknowledges University Grant Commission (UGC), New Delhi, India for financial support received as Research Fellowship. Central Instrument Facility (CIF), Pondicherry University, for utilized scanning electron microscopy facility in the present study greatly acknowledged here.

\section{AUTHORS CONTRIBUTIONS}

Research original idea and manuscript preparation was carried out by corresponding author Prof. K. Srikumar. Experimental design and work, data analysis and manuscript draft preparation were carried out by primary author Dr. V. Athithan. Data analysis, scientific discussion and manuscript proofreading was carried out by second author Prof. R. Ramesh.

\section{CONFLICT OF INTERESTS}

Declared none

\section{REFERENCES}

1. Zhabinskii VN, Khripach NB, Khripach VA. Steroid plant hormones: effects outside plant kingdom. Steroids 2015;97:87-7.

2. El-Hajjaji, Fatim Zorah. Liver X receptors, lipids and their reproductive secrets in the male. Biochim Biophys Acta Mol Basis Disease 2011;1812:974-81.

3. Colin M Tice, Paul B Noto, Kristi Yi Fan, Linghang Zhuang, Deepak S Lala, Suresh B Singh. The medicinal chemistry of liver X receptor (LXR) modulators. J Med Chem 2014;57:7182-205.

4. Ross V Weatherman, Robert J Fletterick, Thomas S Scanlan. Nuclear-receptor ligands and ligand-binding domains. Annu Rev Biochem 1999;68:559-81.

5. Premalatha R, K Srikumar, D Vijayalaksmi, GN Kumar, PP Mathur. 28-Homobrassinolide: a novel oxysterol transactivating LXR gene expression. Mol Biol Rep 2014;41:7447-61.

6. Takatsuto, Suguru, Nobuo Ikekawa, Tadashi Morishita, Hiroshi Abe. Structure-activity relationship of brassinosteroids with respect to the A/B-ring functional groups. Chem Pharm Bull 1987;35:211-6.

7. Muthuraman P, Srikumar K. Induction of hexokinase I expression in normal and diabetic rats by a brassinosteroid isoform. Eur J Pharm Sci 2010;41:1-9.

8. V Athithan, R Premalatha, K Srikumar. Down-regulation of plasma and tissue biomarkers by homocastasterone. Int J Drug Delivery 2014;6:172-8.

9. Prabu M, Kumuthakalavalli R. Antidiabetic potential of the oyster mushroom Pleurotus florida (Mont.) singer. Int J Curr Pharm Res 2017;9:51-4.

10. Bergmeyer HU, Grassl M, Walter HE. Methods of enzymatic analysis. Vol 2. 3rd ed. Deerfield Beach, FL: Verlag Chemie; 1983.

11. Maniatis T, Fritsch EF, Sambrook J. Molecular cloning: a laboratory manual. Cold Spring Harbor, NY: Cold Spring Harbor Laboratory; 1982.

12. Ye Leping, Zhi-Jian Su, Ren-Shan Ge. Inhibitors of testosterone biosynthetic and metabolic activation enzymes. Molecules 2011;16:9983-10001.

13. Ruiz de Galarreta CM, Fanjul LF, Meidan R, Hsueh AJ. Regulation of 3 beta-hydroxysteroid dehydrogenase activity by human chorionic gonadotropin, androgens, and anti-androgens in cultured testicular cells. J Biol Chem 1983;258:10988-96.

14. Schoeller Erica L, Samantha Schon, Kelle H Moley. The effects of type 1 diabetes on the hypothalamic, pituitary and testes axis. Cell Tissue Res 2012;349:839-47. 
15. Baccetti B, La Marca A, Piomboni P, Capitani S, Bruni E, Petraglia $\mathrm{F}$, et al. Insulin-dependent diabetes in men is associated with hypothalamo-pituitary derangement and with impairment in semen quality. Hum Reprod 2002;17:2673-7.

16. Premalatha R, Rajamanickam Jubendradass, S Judith Amala Rani, K Srikumar, Premendu Prakash Mathur. A phytooxysterol, 28-homobrassinolide modulates rat testicular steroidogenesis in normal and diabetic rats. Reprod Sci 2013;20:589-96.

17. Erik G Lund, Laurence B Peterson, Alan D Adams. Different roles of liver $X$ receptor $\alpha$ and $\beta$ in lipid metabolism: effects of a $\alpha$-selective and a dual agonist in mice deficient in each subtype. Biochem Pharmacol 2006;71:453-63.

18. Velan Athithan, Kotteazeth Srikumar. 28-Homocastasterone down regulates blood glucose, cholesterol, triglycerides, SREBP1c and activates LxR expression in normal and diabetic male rat. Chem Biol Interact 2017;277:8-20.
19. Volle DH, Mouzat K, Duggavathi R, Siddeek B, Dechelotte P, Sion $\mathrm{B}$, et al. Multiple roles of the nuclear receptors for oxysterols liver $\mathrm{X}$ receptor to maintain male fertility. Mol Endocrinol 2007;21:1014-27.

20. Aitken RJ, Roman SD. Antioxidant systems and oxidative stress in the testes. Oxid Med Cell Longev 2008;1:15-24.

21. Karimi J, Goodarzi MT, Tavilani H, Khodadadi I, Amiri I. Relationship between advanced glycation end products and increased lipid peroxidation in semen of diabetic men. Diabetes Res Clin Pract 2011;91:61-6.

22. Ricci G, Catizone A, Esposito R, Pisanti FA, Vietri MT, Galdieri M. Diabetic rat testes: morphological and functional alterations. Andrologia 2009;41:361-8.

23. Scarano WR, Messias AG, Oliva SU, Klinefelter GR, Kempinas WG. Sexual behaviour, sperm quantity and quality after shortterm streptozotocin-induced hyperglycaemia in rats. Int Androl 2006;29:482-8. 